\title{
Universiteit
}

Leiden

The Netherlands

\section{Apostasy and public policy in contemporary Egypt: An evaluation of recent cases of Egypt's highest courts}

Berger, M.S.

\section{Citation}

Berger, M. S. (2003). Apostasy and public policy in contemporary Egypt: An evaluation of recent cases of Egypt's highest courts. Human Rights Quarterly, 25(3), 720-740. Retrieved from https://hdl.handle.net/1887/13673

Version: $\quad$ Not Applicable (or Unknown)

License: $\quad$ Leiden University Non-exclusive license

Downloaded from: https://hdl.handle.net/1887/13673

Note: To cite this publication please use the final published version (if applicable). 


\title{
Apostasy and Public Policy in Contemporary Egypt: An Evaluation of Recent Cases from Egypt's Highest Courts
}

\author{
Maurits S. Berger*
}

\begin{abstract}
Apostasy, the abandonment of Islam, can be subdivided into the act of apostasy, and its legal consequences. In Egyptian case law of the past fifty years, only the latter plays a role. The act of apostasy hardly needs to be scrutinized by the courts since it is almost never related to religious conviction, but to legal issues like marriage or inheritance. This was different, however, in the 1996 ruling of the Court of Cassation against the Egyptian Muslim scholar Nasr Abu Zayd: here, the behavior of the accused was the central issue. Still, it will be argued, based on the legal notion of public policy that plays a central role in the issue of apostasy, that the court's ruling was consistent with Egyptian jurisprudence in this matter.
\end{abstract}

\section{INTRODUCTION}

In 1996, the Egyptian Court of Cassation ruled that the writings of the Egyptian Muslim scholar, Nasr Abu Zayd, on Islam constituted an act of apostasy, the abandonment of one's religion. Being declared an apostate by the court resulted in the ugly repercussion that Abu Zayd's marriage was declared void. Human rights organizations were up in arms, and the case

\footnotetext{
* Maurits S. Berger (LL.M. and M.A. in Arabic Studies, University of Utrecht, Netherlands) is a lawyer who specializes in contemporary Islamic law. For the past eight years, he has worked as a researcher in Syria and Egypt, and as a visiting professor at various Dutch and Belgian universities. This article is part of his Ph.D. dissertation on public policy in Egyptian law at the University of Amsterdam.
} 
received international attention. It was a period when Islamists took on the battle for the implementation of Shari'a law to the Egyptian courts. I am of the opinion, however, that Abu Zayd was the victim of principles that traditionally have been upheld by Egypt's judiciary, rather than of an upheaval of Islamic fundamentalism.

These same principles, however, have lead to the apparent contradiction in Egyptian legal discourse between disallowing apostasy, on the one hand, while upholding the international and constitutional right of freedom of religion, on the other hand. Closer reading of most Egyptian apostasy cases, including the Abu Zayd case, reveal that the key lies with the concept of "public policy" (al-nizam al-'amm). I will argue that both the act of apostasy as well as its consequences, which are two entirely different issues, and their relation to the freedom of religion can be understood more clearly in light of the concept of public policy.

In order to do so, I will evaluate the Egyptian case law of the highest civil courts on apostasy from the past fifty years. The main focus will be on the Court of Cassation, which has the most substantive record of apostasy cases, almost exclusively dealing with family and inheritance law. Two other high courts, whose case law will be examined, are the Administrative Courts of the Supreme Council, which deals with conflicts between citizens and state institutions, and the Supreme Constitutional Court. The latter has not ruled on apostasy, but its relevance to this article relates to its interpretation of Islamic law and the freedom of religion in Egypt. The criminal and security courts are not included in this research primarily because they do not deal with apostasy in terms of conversion per se, nor will I pay attention to the views of both "classical" and contemporary Islamic scholars on the issue of apostasy, unless they are referred to by the courts. ${ }^{1}$

\section{THE CONSEQUENCES OF APOSTASY}

It is important to clarify a matter of terminology regarding conversion, which in Egyptian legal discourse is dominated by Islamic jargon. The term apostasy (ridda) is reserved for Muslims. Only a Muslim can "apostate," that is abandon or renounce his religion. Whether the apostate converts to another religion or merely wants to give up Islam is irrelevant. Consequently,

1. See, for instance, the collection of statements and articles on apostasy by prominent contemporary Egyptian orthodox-Muslim scholars related to the 1993 trial of the assassins of Farag Foda, in Muhakama al-Murtaddiyin (Cairo, no date), by Ahmad alSayoufi. 
there is no word in Islamic legal jargon-nor in common Arabic legal or colloquial parlance, for that matter-for conversion by a Muslim. NonMuslims, on the other hand, are not said to apostate, but to "change religion"; the decision by a Christian to give up all religion and truly apostate by becoming an atheist, for example, is apparently unimaginable. Finally, when a non-Muslim converts to Islam, it is said that he has "embraced Islam."

In Egypt, as in many other Muslim states, apostasy enjoys a limbo status. According to Islamic law, apostasy is prohibited, and even is punishable by death. Contemporary Egyptian jurisprudence refers to the prohibition of apostasy, but not to the death penalty. Egyptian statutory law, on the other hand, does not make any reference to apostasy. The omission of any such rule, however, should not be taken as a permission of apostasy, as both the Court of Cassation and the Supreme Administrative Court have ruled. ${ }^{2}$ The Administrative Court voiced the general opinion of Egyptian Muslim society that "it is completely acceptable for non-Muslims to embrace Islam but by consensus Muslims are not allowed to embrace another religion or to become of no religion at all." ${ }^{3}$

Generally speaking, this unacceptability of apostasy manifests itself in two areas. First, apostasy might be reprimanded, or even punished, by relatives of the apostate or other members of society, and sometimes even by police or state security agencies, ${ }^{4}$ but the legal repercussions are very few. Our interest here is the strictly legal side of apostasy, which manifests itself solely in the realm of Egyptian Muslim personal status. Again, no rule

2. Court of Cassation No. 28, Year 33, 19 Jan. 1966; No. 20, Year 34, 30 Mar. 1966. Supreme Administrative Court, No. 240, Year 22, 13 May 1973. Also: State Council in its Legal Ruling (Fatwa) Nr. 804 of 2 Dec. 1962 in which reference is made to an earlier ruling of the Administrative Court, Nr. 195, Year 4, 26 May 1952 (mentioned by A.'Abd al-Barr, Dawr Majlis al-Dawla al-Masri fi Himayat al-Huquq wa al-Huriyat al-Amma 292-99 (1991)).

3. Case No. 20, Year 29, 8 Apr. 1980 (discussed by Ahmed Seif al-Islam Hamad, Legal Plurality and Legitimation of Human Rights Abuses: A Case Study of State Council Rulings Concerning the Rights of Apostates, in Legal Pluralism in the Arab World 222-24 (Baudouin Dupret, Maurits Berger, \& Laila al-Zwaini eds., 1999).

4. Apostasy is not prohibited by the Penal Code, but the police and security agencies regularly are reported to detain-and subsequently, often maltreat or even tortureMuslims accused of apostasy based on either Article $98 \mathrm{f}$ of the Penal Code prohibiting the use of religion to "ignite strife, degrade any of the heavenly religions or harm national unity or social peace," or on the wide powers of the Emergency Laws. These detainees are rarely prosecuted, however, which may indicate that detention and torture merely serve as a way of harassment. The few prosecutions that have taken place were undertaken by the State Security Courts, and mainly targeted authors whose books were considered anti-Islamic by the Islamic al-Azhar Institute. An example is the case of Alaa Hamed whose alleged mockery of Islam in his novels was considered a threat to "national unity" and "social peace." Cf. Human Rights Watch, Human Rights Developments 1993: EGYPT (1993). 
prohibiting apostasy can be found in the codified part of this law, ${ }^{5}$ but should be sought in the remnant non-codified rules that are based on "the prevalent opinion of the Hanafi doctrine."

The rules of apostasy, therefore, are limited to the field of personal status law. This is not surprising, since personal status is one of the few fields of law where the religion of the individual is a determining factor. In Egypt, several religious family laws co-exist: there are one Muslim, six Christian, and two Jewish laws; although the non-Muslim minority in Egypt nowadays is composed almost exclusively of Christians. ${ }^{7}$ To apply the appropriate law, the Egyptian court must first determine the religion of the litigant. There is no such thing as a civil marriage in Egypt-the person without religion, or with another religion other than those covered by the laws mentioned, will be governed by Egyptian Muslim family law. Religion-and hence conversion-therefore are not private matters of the individual, but bear significant legal consequences. Conversion does not only allow a person to take part in sermons in another church, but also implies the application of the family law of that church.

Another aspect of the rules of apostasy is that, within the realm of personal status law, these rules can be found only in case law, since no statutory law exists on the subject. The picture that emerges from analysis of the-quite numerous - Egyptian case law, in this respect, is quite consistent. Apostasy is perceived as a legal impediment to almost all personal status rights by virtue of the apostate having incurred civil death. ${ }^{8}$ The repercussions mentioned in the case law of the Court of Cassation are related mostly to marriage and inheritance. Apostasy renders the marriage of the apostate null and void (batil), results in the separation (tafriq) of the spouses, ${ }^{9}$ and prevents the apostate from entering into a (new) marriage, even with a

5. Laws No. 25 of 1920, No. 25 of 1929, No. 100 of 1985 and No.1 of 2000. In addition, guardianship is codified in Laws Nos. 118 and 119 of 1952, family name, family ties and legal capacity in the Civil Code of 1949, and inheritance law in Laws No. 77 of 1943 and No. 71 of 1946 .

6. Decree on the Organisation of the Shari'a Courts, art. 280 (1931). Within Islamic law, four schools of legal doctrine apply. These schools have spread geographically throughout the Muslim world. The Hanafi school, for instance, applies in most of the Middle East.

7. No exact numbers are available. Estimates of the number of Christians in Egypt vary from three to fifteen million out of a total population of approximately sixty million, with six million (10 percent of the population) being the most commonly used figure.

8. "Apostasy is in a way equal to death" (al-ridda fi ma'na al-mawt). Court of Cassation, No. 20, Year 34, 30 Mar. 1966; No. 162, Year 26, 16 May 1995.

9. Court of Cassation No. 20, Year 34, 30 Mar. 1966; No. 25, Year 37, 29 May 1968; Nos. 475, 478, 481, Year 65, 5 Aug. 1996; No. 25, Year 37, 29 May 1969. Also Supreme Administrative Court No. 240, Year 22, 13 May 1973 (discussed by Seif al-Islam Hamed, Legal Plurality and Legitimation of Human Rights Abuses, in Legal Pluralism in the Arab WORLD, supra note 3, at 225-28. 
non-Muslim. ${ }^{10}$ An apostate is excluded from inheritance, ${ }^{11}$ and all blood ties with his or her children will be considered non-existent, regardless of whether the apostasy of the parent took place before or after their birth. ${ }^{12}$ According to the Court of Cassation, an apostate should be given the opportunity to repent and "return" to Islam, in which case a new marriage contract and dowry are required to resume marital life..$^{13}$ The repentance should be a clear affirmation of re-adopting Islam, but the Court also has taken as sufficient affirmation the fact that the new passport that was requested by the apostate mentioned "Muslim" as religion; in Egypt, one's religion is registered in personal identity certificates. ${ }^{14}$

It is a well-known fact that few Muslims convert to another religion. This also applies to Egypt. Still, the case material mentioned above shows that there have been quite a few legal actions involving apostates in Egypt. From this case law, it appears that this phenomenon can be attributed to the use and abuse of apostasy as a legal strategy in the family court. For instance, according to Egyptian inheritance law, which is based on Islamic law, intestate succession between Muslims and non-Muslims is not allowed. ${ }^{15}$ Many of these cases show the sorry sight of siblings and relatives accusing each other of apostasy in order to exclude the other from the inheritance. Another example is the prohibition of marriage between a Christian man and a Muslim woman. Since it is both socially and legally impossible for the woman to denounce Islam and adopt Christianity, it is usually the man who will convert to Islam in order to marry his fiancée. However, in the case when he merely converted to fulfill the condition of marriage, remaining truthful to his Christian faith renders him an apostate. ${ }^{16}$ Also, due to the sheer impossibility under Christian laws to obtain a divorce, a woman may resort to converting to Islam to render the marriage with her Christian husband void. And a Christian husband, who is faced with the

10. Such marriage is "considered as not concluded." Cases No. 20, Year 34, 30 Mar. 1966; No. 9, Year 44, 24 Dec. 1975; No. 162, Year 62, 16 May 1995.

11. Cases No. 28, Year 33, 19 Jan. 1966; No. 17, Year 39, 10 Apr. 1974; No. 162, Year 62, 16 May 1995. Also Legal Ruling (Fatwa) Nr. 804 of 2 Dec. 1962 by the Advisory Section of the State Council (discussed by 'Abd al-Barr, supra note 2, at 292-99) and Supreme Administrative Court No. 240, Year 22, 13 May 1973.

12. Cases No. 9, Year 44, 24 Dec. 1975; No. 162, Year 62, 16 May 1995.

13. Cases No. 34, Year 55, 27 Nov. 1990; Nos. 475, 478, 481, Year 65, 5 Aug. 1996.

14. Case No. 37, Year 32, 21 Apr. 1965.

15. Law 73, art. 6 (1) (1947).

16. The Supreme Administrative Court was asked to look into the case of a Christian widow of a Christian university professor. She was considered an apostate for having previously converted to Islam and then reverted to Christianity in order to marry her husband. The fact that the civil court case had been filed by the deceased's sister gave reason to believe that it was her intention to exclude her brother's wife from the inheritance. (Case No. 240, Year 22, 13 May 1973.) 
same legal obstacles to divorce, may opt for conversion to Islam to obtain the right to divorce his wife by means of repudiation (talaq). ${ }^{17}$

\section{PUBLIC POLICY (1)}

In Egypt, apostasy usually becomes a legal issue only with regard to its consequences, which are limited to the field of personal status. Accusations or self-proclamations of apostasy before the court, therefore, mostly serve purposes that do not necessarily have any relation to the apostate's religious convictions. The "civil death" incurred by apostasy merely creates several legal impediments as to the validity of the marriage and the inheritance. An apostate, for instance, may not marry, or when already married, should be divorced, and an apostate is not entitled to inherit or to bequeath. These impediments are the "rules of apostasy," and both the Court of Cassation and the Supreme Administrative Court have held that these rules pertain to public policy. ${ }^{18}$

The concept of public policy (al-nizam al-'amm) was introduced into Egyptian law along with many other European-primarily French-legal concepts, which were adopted in Egypt by the end of the nineteenth century. It stands for those legal principles that are considered fundamental to a society, and which may not be contradicted, altered, or violated by any rules or laws of that same society. Public policy usually refers to foreign law: while domestic conflicts rules may decide on the admissibility of a foreign law, application of this law may be rebutted when it violates domestic public policy. The cases of domestic law itself violating public policy will be few, since domestic laws are based on the very same fundamental principles that constitute public policy. In the case of apostasy, the Egyptian judiciary has maintained the principle that the rules of apostasy constitute rules of public policy. Not attaching any legal consequences to apostasy, therefore, is tantamount to violating Egyptian public policy.

In order to explain the reasoning behind the public policy character of the rules of apostasy, we have to go back to the definition of public policy itself. In several rulings the Court of Cassation has defined public policy as "the social, political, economical or moral principles in a state related to the highest (or essential) interest (maslaha 'ulya, or: masalih jawhariyya) of society," or as "the essence (kiyan) of the nation." ${ }^{19}$ In the legal literature,

17. Cf. Maurits Berger, Public Policy and Islamic Law: The Modern Dhimmi in Contemporary Egyptian Family Law, 1 Islamic L. \& Soc'y (2001).

18. Cf. Supreme Administrative Court, No. 240, Year 22, 13 May 1973. Court of Cassation, No. 9, Year 44, 14 Dec. 1975 and Nos. 475, 478, 481, Year 65, 5 Aug. 1996.

19. Cases No. 308, Year 29, 25 June 1964; No. 371, Year 32, 5 Apr. 1967; No. 22, Year 34, 7 Nov. 1967; No. 59, Year 39, 12 Feb. 1975; No. 7, Year 48, 19 Jan. 1977; No. 714, Year 47, 26 Apr. 1982; No. 1259, Year 49, 13 June 1983. 
generally, reference is made either to this Court ruling or to the similar definition presented by the late jurist, al-Sanhuri, who is still a legal authority in Egypt, which further defines the general interest as always predominating the interests of individuals. ${ }^{20}$ The "principles" or "interest" that make up public policy are never clearly delineated, as they depend on the particular circumstances of a given society at a given time. Their definition, therefore, is left to the courts, as they are deemed the best suited to establish, on an ad hoc basis, when a legal act or statute should be considered a violation of public policy.

All of this is consistent with the general definitions used in most European legal systems. In Egyptian legal discourse, however, there is no doubt that a major element of Egyptian public policy is the "essential principles of Islamic law" (al-mabadi al-asasiyya fi ahkam al-shari'a alislamiyya). ${ }^{21}$ The Court of Cassation, in several instances, has stated that these rules pertain to public policy due to their "strong link to the legal and social foundations which are deep-rooted in the conscience of [Egyptian] society." 22 Both the Court of Cassation and the legal literature define the "essential principles of Islamic law" as the principles that are considered fixed and indisputable (nass sarih qati' al-thubut wa qati' al-dalala). ${ }^{23}$ The phrase "fixed and indisputable rules" is a technical term used in the Islamic literature for rules of Islamic law that are not subject to change or interpretation. This terminology also is used now in contemporary Egyptian legal discourse. ${ }^{24}$

20. A. al-Sanhuri, 3 Masadir al-Haqq fi al-Fiqh al-Islami, 81 (1953), quoted in 1 AL-WAST FI Sharh al-QAnun al-Madani 399 (1964).

21. S.'Abd al-Wahhab, al-Nizam al-'Amm fi al-Ahwal al-Shakhsiyya fi Masr, 39 al-MUнаман 350 (1958); R. Abu Sa'ud, Was t fi Sharh al-'Ahwal al-Shakhilya li-Ghayr al-Muslimin 425-26 (1986); H. al-'Ahwani, Sharh Mabadi' al-'Ahwal al-Shakhilya li-L-Masihiyin al-Masriyin 180 (1993/94); M. Jarihl, Mukhtasar al-'Ahkam al-Shar'IYYa fl al-'Ahwal al-ShakhsiYya li-ghayr alMuslimin 53 (1984/85); A. Ma'mun, Durus fi al-'Ahwal al-Shakhsiyra li-ghayr al-Muslimin 39 40 (1984); M.H. Mansur, al-Nizam al-Qanuni li-L-Usra fi al-Shawiri' ghayr Islamirya 44 (1983); M. Muhammad, AhKam al-'Ahwal al-ShakhsiYya Ll-GHayr al-Muslimin min al-Mariyin 159 (1997); A. Mursi, Mabadi' al-'Ahwal al-Shakhsiyya li-l-Masriyin GHayr al-Muslimin 191-93 (1996); A.H. Nalidah, Mabadi' al-'Ahwal al-Shakhsiyya li-ghayr al-Muslimin 53 (1998/99); A.A. Salamah, al-Maqsud bi-Ahkam al-Shari'a al-Islamiya allati tanabiqu fi Masa'il alAhwal al-Shakhsiyya li-ghayr al-Muslimin, Majallat al-Ulum al-QAnuniYya Wa al-IQtisadiYya,

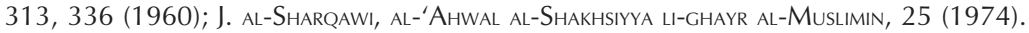

22. No. 17, Year 32, 27 May 1964; No. 482, Year 50, 14 June 1981; No. 36, Year 61, and No. 154, Year 63, 25 Dec. 1995.

23. 'Abd al-Wahhab, supra note 21, at 350; $A_{B} \cup S_{A}$ ' $\cup D$, supra note 21, at 437; al-'Ahwani, supra note 21, at 180; M.A. 'ARafa, Al-Qanun al-Duwall al-Khass; al-Kitab al-Thani fl alTANazu' al-Duwali li-L-QAWANIn 141 (1993); A. Khallaf, Tafsir al-Nusus al-Qanuniyya wa Ta'wilu-hu 31 Munamat 188 (1950/51); Mursi, supra note 21, at 192.

24. The Supreme Constitutional Court gave an extensive definition of this term in several rulings in the 1990s, explaining that the Egyptian legislature was allowed only to amend, change, or re-interpret those rules of Islamic law of a "relative" nature, while those of an "absolute" nature were not subject to any change or interpretation. In its 1993 ruling, the Court phrased this as follows: 
Examples of such undisputable rules are the unilateral right of the husband to divorce his wife (talaq), the right of polygyny, and the prohibition for a Muslim woman to marry a non-Muslim husband. ${ }^{25}$ According to the Court of Cassation $^{26}$ and the State Council, ${ }^{27}$ the rules of apostasy also pertain to these undisputable principles.

The public policy nature of most of these rules had to be emphasized because they are not codified. In the case of apostasy, the Court of Cassation and the Supreme Administrative Court disproved the claim that the rules of apostasy did not apply since they were not mentioned in any law. Indeed, these rules are not codified, the courts argued, but nevertheless, they apply since they pertain to the fundamental legal order of Egyptian society, that of public policy. ${ }^{28}$

So far, with regard to the consequences of apostasy, Egyptian case law has been consistent and relatively clear. The apostasy case of Nasr Abu Zayd was based on these very same rules, but was exceptional for two reasons. First, the issue at hand essentially was not of family law but of apostasy itself. Second, public policy was to play an important role in the alleged contradiction between the prohibition of apostasy and the freedom of religion. Both will be discussed below.

Article 2 of the Constitution means that a stipulation of law (nass tashri $i$ ) may not contradict the Shari'a rules which are absolute in their origin and significance (al-ahkam al-shara'iyya alqata'iyya fi thubuti-ha wa dalalati-ha.) These are rules that may not be interpreted (la yajuz alijtihad fi-ha). They represent the general principles and immutable fundamentals (al-mabadi' alkulliyya wa al-'usul al thabita) of the Islamic Shari'a that do not tolerate interpretation or change (ta'wil aw tabdil). Hence, it is unimaginable that their meaning (mafhum) is subject to change in time and place. This is different for the rules that are of a relative nature (al-ahkam al-zanniyya), whether in their origin or significance or both; interpretation is confined to them and does not extend beyond them, and they change with time and place to safeguard their flexibility and vitality. It is necessary, however, that this interpretation takes place within the framework of general fundamentals (al-'usul al-kulliyya) of the Islamic Shari'a.

(SCC No. 7, Year 8, 15 May 1993 (see for French translations: Nathalie BernardMaugiron, Legal Pluralism and the Closure of the Legal Field: The al-Muhajir Case, in Legal Pluralism in the Arab World, supra note 3, at 116; Baudouin Dupret, A propos de I'affaire Abu Zayd, universitaire poursuivi pour apostasie; le procès, I'argumentation des tribunauxi, MAGHR B-MACHREK (1996)). The SCC gave an English summary of this ruling in 56 The Role of the Judiciary in the Protection of Human Rights (1997), but I find its translation inadequate.)

In a subsequent ruling, the Supreme Administrative Court used similar wordings (No. 5257, Year 43, 28 Dec. 1997). In a ruling fifteen years earlier, this court spoke in more general terms of "the preservation and protection of Divine rights" (No. 240, Year 22, 13 May 1973).

25. For a full inventory of these rules and court rulings see Berger, supra note 17.

26. Cases No. 28, Year 33, 19 Jan. 1966; No. 20, Year 34, 30 Mar. 1966.

27. Thus the Islamic Shari'a applies to a Muslim ... . and it is a matter of consensus that the Islamic Shari'a contains certain rules dealing with personal status affairs that may not be ignored, since they are part of public order. Among these are the rules concerning apostasy. . . . In ruling that an apostate's marriage is invalid, Divine rights are preserved and protected.

(Case No. 240, Year 22, 13 May 1973.)

28. Court of Cassation and Supreme Administrative Court, supra note 2. 


\section{APOSTASY: THE ACT ITSELF}

Muslims have no choice when it comes to religion. A child is born a Muslim if his father is a Muslim. There is no need to reassert the faith at a later age. ${ }^{29}$ How then does a court establish the fact of apostasy, that is, the abandonment of the Islamic faith? ${ }^{30}$ Based on the case law, it is proven mostly with documents, such as affidavits of conversion, or identification cards, and marriage and divorce certificates, on which the religion of the persons in question is registered. But without written evidence, apostasy is hard to prove. $^{31}$

The case of Nasr Abu Zayd ${ }^{32}$ is unique in the legal landscape of apostasy cases in several respects. First, the accusation of apostasy did not serve any legal purpose related to personal status law. Why would a claimant go to such lengths to prove someone's apostasy? It appears that the Abu Zayd case served no other purpose than settling personal or political

29. Court of Cassation, No. 44, Year 40, 29 Jan. 1975. In this case, the Court ruled that if the father of the child converts to Islam after his child is born, the child automatically becomes a Muslim if he is less than fifteen years old (the age when a person is considered to be physically and intellectually mature (baligh wa 'aqil)).

30. In cases of conversions among non-Muslims ("changing religion"), the decision as to whether or not a conversion has taken place is to be made by the religion, rite, or sect to which one converts, and not the one that is being abandoned (Court of Cassation, No. 29, Year 34, 30 Mar. 1966; No. 2, Year 37, 31 Jan. 1968; No. 28, Year 37, 31 Jan. 1968; No. 44, Year 40, 29 Jan. 1975). The fact that the law of the abandoned religion might oppose the conversion and consequently deem the marriage null and void is of no consequence. The request by a Jewish husband for nullification of his marriage in accordance with Jewish law because of his conversion to Islam therefore was denied (Court of Cassation, No. 20, Year 36, 7 May 1969).

31. The following case is illustrative of how complex things might become. A Christian man has a child, then converts to Islam and has another child. Based on the rule that the child follows his father in religion, the first child is Christian and his sibling Muslim. When the father died, both children claimed the full inheritance with the exclusion of the other child because of the difference with the deceased's religion. The Muslim child had the advantage because there was clear evidence of his father's conversion to Islam. The Christian child then proceeded by claiming his father's apostasy, but was unable to build a case. (Court of Cassation, No. 17, Year 39, 10 Apr. 1974.)

32. Court of Cassation, Nos. 475, 478, 481, Year 65, 5 Aug. 1996 (hereinafter "Court of Cassation 5 Aug. 1996"). For lengthy extracts of the Appeal Court and Court of Cassation see Maurits Berger \& Baudouin Dupret, Jurisprudence Abu Zayd: Extrats des arrests du Tribunal d'Instance de Giza, de la Cour de l'Appel du Caire (traduit vers le français) et de la Cour de Cassation (traduit vers l'anglais), in Dro ts d'Egypt: Histolre et Sociologie, Egypt Monde Arabe (Centre d'Etudes et de Documentation Economique et Juridique (2nd Sem. 1998)). For commentaries see, e.g., Kilian Bälz, Submitting Faith to Judicial Scrutiny Through the Family Trial: The Abu Zayd Case, 37 Die Welt des Islams 135-55 (1997); Baudouin Dupret, A propos de l'affaire Abu Zayd, universitaire poursuivi pour apostasie; le procès; I'argumentation des tribunaux, supra note 24; Baudouin Dupret \& Jean-Noel Ferré, Participer au pouvoir, c'est édicter la norme: À propos de l'affaire Abu Zayd (Egypte 1992-1996), 47 ReVue françalse de science pol tiQue, 762-75 (1997). 
scores. ${ }^{33}$ In order to do so, Abu Zayd's accusers made clever use of the existing rules in Egyptian law and jurisprudence on apostasy.

The first legal obstacle they had to overcome was one of procedure: the law required a "personal interest," such as any direct legal purpose, interest, or right, other than the mere accusation of apostasy itself by the claimants. Since the claimants did not have any such direct and personal interest in their accusation of Abu Zayd's apostasy, they referred to the procedure of hisba, which allows any Muslim to file a case against a fellow Muslim suspected of violating the so-called "rights of God," or the essential elements of the Islamic faith. ${ }^{34}$ The use of the hisba procedure was an issue of legal controversy among the courts, ${ }^{35}$ but was used successfully against Abu Zayd. ${ }^{36}$ By opting for this legal approach, however, the claimantsseveral individuals with no relation to Abu Zayd, except for a concern for Abu Zayd's interpretation of Islam-could not suffice with the demand for a court ruling on Abu Zayd's apostasy: they had to invoke his apostasy as a legal impediment to his marriage. In other words: while the affirmation of Abu Zayd's apostasy was effectively the goal, it had to be legally constructed as the means.

The second unique feature of the Abu Zayd case was that his alleged apostasy was not related to conversion on his part, but to blasphemy. This was a matter of legal evidence: Abu Zayd's apostasy was not based on a document or self-pronounced conversion, but on his writings on Islam. In the light of Abu Zayd's insistence on being a Muslim and his writings being in conformity with his Islamic beliefs, the Court had to embark on the

33. In the case of Nasr Abu Zayd, a referee reader of the committee in charge of evaluating Abu Zayd's work in order to grant him the position of professor had deemed his work anti-Islamic. It is upon the instigation of Abu Zayd's accuser that his alleged apostasy was brought before the court. According to Abu Zayd, a personal grudge was involved. See Nasr Abu Zayd, Inquisition Trial in Egypt, ReCHT VAN DE IsLAm, 48 (1998).

34. Since the Abu Zayd case, much has been written on hisba. See, e.g., Bälz, supra note 32, at 138-43; Jörn Thielmann, La jurisprudence égyptienne sur la requête en hisba, in Dro ts d'Egypt: Histolre et Sociologie, Egypt Monde Arabe, supra note 32, at 81; Ahmad SubHi Mansur, al-HIsba: dirasa 'UsuliyYa tarikHiYya (1995).

35. For instance, in the Abu Zayd case, hisba was rejected by the Court of First Instance, but accepted by both the Court of Appeal and the Court of Cassation, while in the abovementioned Muhajir case, which took place at the same time, hisba was accepted in the first instance but rejected in the summary appeal proceedings.

36. While the Abu Zayd case was pending before the Court of Cassation, hisba has been relegalized as a procedure in which the claimant can merely make a complaint with the Prosecutor's office, who at his own discretion may decide whether he will press charges (CIVIL Code art. 3 (1996)). This amendment was invoked by Abu Zayd's defense counsel, but the Court decided that a change of law could not affect a pending case. In April 2001, the Egyptian Public Prosecutor was petitioned to prosecute the Egyptian feminist writer Nawal al-Saadawy, who was declared a heretic by the Egyptian Grand Mufti for her critical remarks on principal matters of Islam, such as the veil, the pilgrimage and inheritance law. The Prosecutor's office refused, and the subsequent plea to the court for divorcing al-Saadawy from her husband was rejected also. 
difficult task of evaluating these writings in order to decide whether he was indeed guilty of blasphemy, and consequently, apostasy. This kind of accusation has happened to other Egyptian Muslims before, often by the Islamic Research Institute at Al-Azhar, which censors books on their Islamic value, and occasionally, by Islamic extremists, but those cases were never taken to court. ${ }^{37}$ Most cases that were brought before the Court were accusations of non-conformity with Islam rather than apostasy; the claimants demanding the ban of a book ${ }^{38}$ or film, ${ }^{39}$ or a governmental decree. ${ }^{40}$

Finally, the third unique feature of the Abu Zayd case was that the Court of Cassation allowed takfir, declaring a Muslim a non-believer; although, the Court did not mention this expression in so many words. This is a very controversial issue, since such an accusation is considered one of the "greater sins" in Islam, to be exercised only with great caution due to its complexity and grave consequences. ${ }^{41}$

The Nasr Abu Zayd case, therefore, constitutes a key ruling in the case

37. One of the first accusations was made against the-nowadays renown scholar-Taha Hussain for the content of his Ph.D. dissertation written at the Azhar University in the 1930s. Such an accusation cost the life of the Egyptian writer and human rights activist, Farag Foda, who was very critical of the Islamic establishment. He was shot dead by an Islamic extremist in 1992, one week after he had been branded an apostate by the alAzhar. Two years later, there was an assassination attempt on the novelist Naguib Mahfouz after he had been declared an apostate by an Islamic extremist group. In 1997, the al-Azhar Front for Scholars accused Hassan Hanafi, a philosophy professor at Cairo University, of apostasy, but the case was never pursued and faded away without any repercussions for Hassan Hanafi. See, e.g., Article 19, The Egyptian Predicament: Islamists, The State and Censorship 47-55 (1997). To my knowledge at the time of writing, the latest accusation of apostasy and heresy was made against the abovementioned Nawal alSaadawy by the Egyptian Grand Mufti (see, e.g., At-Ahram Weekly, 12 Apr. 2001, No. 529).

38. To my knowledge at the time of writing, no cases related to books of alleged un-Islamic content have been brought before a civil court. The Islamic Research Institute at AlAzhar University has legal authority to censor books on conformity with Islamic dogma but, by lack of authority to confiscate, usually will refer these cases to the State Security Court.

39. For instance, the film al-Muhajir (the Emigrant) by Youssef Chahine, was said to recount the life of Joseph, who is considered a prophet in Islam and, therefore, may not be portrayed by an actor. The film was ultimately banned on procedural rather than substantive grounds. (See the analysis by Bernard-Maugiron, supra note 24, at 173-89.)

40. For instance, the 1994 decree by the Ministry of Education banning the head scarf at schools, and the 1996 decree by the Ministry of Health prohibiting the practice of female circumcision (both extensively discussed by Kilian Bälz, The Secular Reconstruction of Islamic Law: The Egyptian Supreme Constitutional Court and the "Battle over the Veil" in State-Run Schools, in Legal Pluralism in the Arab World, supra note 3, at 229-44, Kilian Bälz, Human Rights, the Rule of Law and the Construction of Tradition: The Egyptian Supreme Administrative Court and Female Circumcision, in Dro ts D'EGypt: HistolRE ET Sociologie, Egypt Monde Arabe supra note 32, at 141-54.

41. Cf. Mohammad Kamali, Freedom of Expression in Islam 186 (1997). See also (the former Mufti of Egypt), Shaykh Mohammed al-Tantawi, Al-Ahram 8 Dec. 1981 \& 10 Nov. 1992. Both scholars point out that only a learned person like a judge or jurisconsult (mufti) is entitled to declare someone an infidel. 
law of the Court of Cassation. For the first time, the Court defines what apostasy is and how it can be committed. In this ruling, the Court adheres to the principles of Islamic doctrine by defining apostasy as "a clear declaration of unbelief (kufr)" by a Muslim. As long as a Muslim does not proclaim himself an apostate, however, he cannot be considered one. Only Muslims who openly denounce Islam can be considered apostates. In the words of the Court:

Merely believing the mentioned [unbelief] is not considered apostasy, unless it is embodied in words or actions. According to the majority of the Muslim legal scholars, among them the Hanafis, it suffices to consider a person an apostate once he deliberately speaks or acts in unbelief, as long as he meant to be degrading, contemptuous, obstinate, or mocking. ${ }^{42}$

The Court's definition reflects the overlap in Islamic doctrine of the definitions of apostasy, blasphemy, unbelief, and heresy, ${ }^{43}$ all of which are used by the Court in different meanings, but with the single unifying factor that they all lead to apostasy. Based on the publications written by Abu Zayd in his capacity as a professor of Arabic Language and Islamic Studies at the Liberal Arts Faculty of Cairo University, where he was teaching Quranic Sciences, the Court found him guilty (as if it were a criminal court) on all three charges. The Court's reasoning-among others—is as follows:

He denounces that the Quran is the word of God, describing it as "a cultural product," . . . and as being affiliated to a human culture, rendering it an incarnated human text. . . .

He describes [Islam] as an Arabic religion, denying its universality and availability to everybody. ... .

He attacks the application of the Shari'a by describing it as backward and reactionary. He claims that the Shari'a is the reason behind the backwardness of Muslims and their degradation. ... He states that abiding by Shari'a texts is contradictory to civilization and progress and hinders the proceeding of life. He accuses the theological method as clashing with the mind by stating that "there is a battle being fought by the powers of the superstition and myth in the name of religion and literal meanings of religious texts and by the intellectual powers

42. Court of Cassation 5 Aug. 1996, supra note 32.

43. Blasphemy (sabb Allah wa sabb al-Rasul) generally is subsumed under apostasy (ridda), since the Muslim blasphemer is assumed to renounce his religion also. The Court defines it as

[S]corning the Quran or the Prophetic Sunna, or mocking, repudiating, or disavowing them, or intentionally claiming anything contradicting them publicly or haughtily, or doubting any of it, ... denying God's existence or His creation as mentioned in the Quran, ... repudiating the Prophecy of Mohammed—peace be upon him—or in general his prophecy to all people, or doubting his sincerity.

Both blasphemy and apostasy may be considered unbelief or denial of Islam (kufr), or amount to heresy (zandaqah). See Carl Ernst, Blasphemy: The Islamic Concept, 2 THE EnCYClopedia of Religion, (1987); KAmali, supra note 41, at 212-21. 
of progress trying to fight sometimes with superstition on its own ground." This is clear unbelief! . . .

He goes as far as calling for a liberation from Shari'a Texts, claiming that they lack any essential and fixed elements, and that they only express a historic phase which has passed. This is an accusation that the law of God is not suitable for all times. ...

He denies that God Almighty is [physically] on His great Throne and that His Chair encompasses the Heavens and Earth, and that He created Paradise, Hell, Angels and Demons, although the Qur'anic verses categorically stipulate all that. ... .

He boldly proceeded in this approach, which is opposed to Islam in its meanings, dogmas and fundamentals, denying the main fundamentals of its sacredness. He did not hesitate to contradict established truths, even historic ones. ... while he was fully aware of its meaning and truth within the balance of the Shari'a. ${ }^{44}$

It may be clear from these excerpts that the Court adheres to a strict interpretation of Islam. In addition, the Court takes the very conservative stand that an unbeliever-and hence apostate-is also the Muslim who takes a too liberal point of view in interpreting Islamic tenets, ${ }^{45}$ or claims that the Islamic Shari'a is not fit for application nowadays. The last two definitions of "unbelief" are a clear warning to the Muslim liberals and secularists, respectively.

Abu Zayd's claim that his writings were not against Islam because he was a believing Muslim turned out to be the noose around his neck:

$\mathrm{He}$ is an apostate, because he has revealed his unbelief after having been a believer, even if he claims to be a Muslim. ... An apostate cannot be excused when he claims to be a Muslim, because he has adopted a stance contrary to Islam. But then a heretic (al-zandiq) usually talks about his infidelity and proclaims his wrong faith while at the same time claiming that he is a Muslim. (Court of Cassation 5 Aug. 1996)

\section{PUBLIC POLICY (2)}

In the Abu Zayd case the Court also linked apostasy with public policy, but did so in a quite different manner. The rules of apostasy, as discussed in the first paragraph, usually are dealt with in a rather matter-of-fact way: when one apostates, one has to face the consequences. Public policy was merely

44. Court of Cassation 5 Aug. 1996, supra note 32.

45. This, the Court argues, cannot be tolerated "because the proofs of their existence are evident: the Qur'an and Sunna are full of them and they are accepted by consensus." An example of this offense is "proclaiming that the Quran is not coming from God or that it is man-made." 
a means to ground these consequences into the Egyptian legal framework. In this respect, apostasy pertains to public policy for two reasons: a) because these rules were based on essential principles of the Islamic Shari'a, and b) to ascertain their applicability in light of a lack of any statutory rules.

In the case of Abu Zayd, however, public policy acquires an entirely different role. The consequences of apostasy are not the issue here, but the protection of the orthodoxy of Islam. In the words of the Court of Cassation:

To depart from Islam is to revolt against it, and this necessarily finds its reflection in the loyalty of the individual to the Shari'a, the state, and his ties with the society. This is what no law or state tolerates.... No individual has the right to proclaim that which contradicts the public policy or morals (al-nizam al-'amm aw al-'adab), use his opinion to harm the fundamentals upon which the society is built, to revile the sacred things, or to disdain Islam or any other heavenly religion. ${ }^{46}$

In this respect, public policy goes beyond the legal proportions, and gains a moral and metaphysical dimension. Protection is the key word here. Egyptian legal scholars have argued that public policy serves the "protection of the rights of the Muslim" (himayat huquq al-muslim), ${ }^{47}$ or that its rules are equal to the "rights of God" (huquq Allah). ${ }^{48}$ In both instances, the scholars' meanings are the same: God has granted the Muslims certain "rights" that are "definite," and hence, inalienable. ${ }^{49}$ The legal consequence of apostasy is one of these rules that need to be "protected," or strictly adhered to. Deviation from these rules is tantamount to a violation of public policy. And this is where apostasy has acquired its second meaning in the Abu Zayd case: the public attack on, or doubt of, any of the fundamental rules of Islam.

\section{FREEDOM OF RELIGION}

As mentioned in the introduction, it is the concept of public policy that may help to solve the riddle of the apparent contradiction of Egyptian jurisprudence disallowing apostasy, on the one hand, while upholding the freedom of religion on the other. In order to do so, some general remarks have to be

46. Court of Cassation 5 Aug. 1996, supra note 32.

47. This is discussed extensively in Maurits Berger, Conflicts Law and Public Policy in Egyptian Family Law: Islamic Law through the Back Door, 3 Ам. J. Comp. L. (2002).

48. See, e.g., Sanhuri, supra note 20, at 93.

49. It should be born in mind that the term "rights" is misleading because the rules contain both rights (the husband has the right to divorce his wife by repudiation) and obligations (the woman must keep a waiting period-idda - after divorce or death of her husband), as well as general injunctions (a Muslim woman is not allowed to marry a non-Muslim man). 
made about how the freedom of religion is embedded in the Egyptian legal framework.

The freedom of religion is mentioned in the Egyptian constitution as well as in numerous instruments of international law to which Egypt is party. Both will be discussed in detail below. With respect to the international human right of freedom of religion, Egypt's position must be seen within the wider framework of the Muslim world. Most Muslim states maintain that Muslims are not allowed to abrogate their faith. ${ }^{50}$ This view was not yet vigorously defended by the few independent Muslim states during the discussions of the (non-binding) Universal Declaration of Human Rights (UDHR) of 1948, which stipulates in Article 18:

Everyone has the right to freedom of thought, conscience and religion; this right includes freedom to change his belief, and freedom, either alone or in community with others and in public or private, to manifest his religion or belief in teaching, practice, worship and observance. ${ }^{51}$

The Muslim states were more alert with the (binding) International Covenant on Civil and Political Rights (ICCPR) of 1966, which Egypt ratified in 1982. ${ }^{52}$ It was through their instigation that Article 18 of the UDHR, which allowed the "freedom to change his belief," was amended to "freedom to have or adopt a religion or belief of one's choice." ${ }^{\prime 53}$ Although this still appears to give a person the freedom to change his or her religion, Egypt is of the opinion that this provision does not violate "the rules of Shari'a law." 54

50. See, e.g., Ann E. Mayer, Islam and Human Rights, Trad tion and Pol tics, 142 (2d ed. 1995).

51. Universal Declaration of Human Rights, adopted 10 Dec. 1948, G.A. Res. 217A (III), U.N. GAOR, 3rd Sess. (Resolutions, part 1), at 71, U.N. Doc. A/810 (1948) art. 18, reprinted in 43 Am. J. INT'L L. Supp. 127 (1949).

52. International Covenant on Civil and Political Rights, adopted 19 Dec. 1966, G.A. Res. 2200 (XXI), U.N. GAOR, 21st Sess., Supp. No. 16, U.N. Doc. A/6316 (1966), 999 U.N.T.S. 171 (entered into force 23 Mar. 1976) (hereinafter ICCPR).

53. See, e.g. Donna E. Arzt, The Application of International Human Rights in Islamic States, 12 Hum. Rts. Q. 214-18 (1990); Brice Dickson, The United Nations and Freedom of Religion, 44 INT'L \& COMP. L.Q. 342 (1995); MAYER, supra note 50, at 142.

54. Egypt, upon ratification of the covenant in 1982, added the following statement: "Taking into consideration the provisions of the Islamic Shari'a and the fact that they do not conflict with the text [i.e. the Covenant] . . . we accept, support and ratify it." This could be explained as an exception clause, but is more likely to be an assurance that the ICCPR is consistent with the Islamic Shari'a. See Donna E. Arzt, Heroes or Heretics: Religious Dissidents under Islamic Law, 14 WIS. INT'L L.J. 397 (1996). In addition, The Human Rights Committee established by the ICCPR to receive and review reports from member states as to their compliance with the Covenant, has asked questions about the possible conflict between the Covenant and the Shari'a, but according to Egyptian government officials there was no contradiction between the two. Kevin Boyle, International Human Rights Law and the Egyptian State, in Human Rights and Democracy: The Role of the Supreme Constitutional Court of Egypt 75-76 \& 81-82 (Kevin Boyle \& Adele Omar Sherif eds., 1996). 
As to the Egyptian Constitution, Article 46 reads: "The state shall guarantee the freedom of belief and the freedom of practice of religious rites." 55 Article 2, which is of importance in the discussion of Article 46 reads: "The Islamic Shari'a is the main source of legislation."56

While the interpretation and application of the Constitution is the exclusive prerogative of the Supreme Constitutional Court, the international treaties signed by Egypt may be applied directly by the Egyptian courts or called upon by Egyptian litigants. ${ }^{57}$ These rules are not adhered to strictly, however, since constitutional rights also were invoked before and discussed by the Court of Cassation in the Abu Zayd case, without reference being made to the same rights as stipulated in international treaties.

Procedural matters being as they may, the issue of substantive law was dealt with as follows: Egyptian legal discourse confines the scope of freedom of religion usually to non-Muslims in Egypt. It is often stated both in case law and legal literature that the constitutional "freedom of belief" means that non-Muslims should be free to practice their faith unhindered, as well as administer their own religious affairs, including family law. ${ }^{58}$ Similarly, conversion by non-Muslims, which effectively means that a religion or church is abandoned to embrace another, also is not to be interfered with, as the Court of Cassation has ruled on many occasions ${ }^{59}$ : "it is standard jurisprudence of this court that it is up to the person to change his rite or sect (milla aw ta'ifa $\left.{ }^{60}\right) .^{\prime \prime}$

With regard to Muslims, on the other hand, the situation is considered to be completely different. The most clarifying explanation in this respect has been given by the Supreme Constitutional Court in the case of "the battle of the veil." The decree of the Minister of Education banning the veil from state schools was opposed before the Court with the argument that such prohibition violated the freedom of belief. The Court rejected this plea, pointing out the difference between the "freedom of belief" and the

55. Egypt CONSt. art. 46.

56. Id. art. 2.

57. Id. art. 151.

58. See, e.g., H. al-hwani, Himayat al-Hurriyat al-Shakhsiyya fi Rawabit al-Qanan al-Khass, 33 Majallat al-'Ulum al-Qanunirya wa al-Igtisadiyya 58-59 (1991); see also State Council (Supreme Administrative Court) No. 501, Year 4, 25 Apr. 1959 (discussed by 'Abd alBarr, supra note 2, at 283-90).

59. Case No. 17, Year 43, 5 Nov. 1975. Also: No. 3, Year 35, 23 Mar. 1966; No. 29, Year 34, 30 Mar. 1966; No. 2, Year 37, 31 Jan. 1968; No. 5, Year 41, 11 Apr. 1973; No. 3, Year 46, 29 Feb. 1976; No. 3, Year 46, 29 Dec. 1976; No. 21, Year 45, 9 Mar. 1977; No. 23, Year 46, 26 Apr. 1978; No. 29, Year 47, 28 Mar. 1979; No. 5, Year 48, 16 Apr. 1980; No. 46, Year 48, 17 Jan. 1981; No. 41, Year 54, 9 Apr. 1985; No. 68, Year 53, 24 Dec. 1985; No. 40, Year 62, 27 Nov. 1995; No. 280, Year 62, 16 Dec. 1996.

60. Milla and ta'ifa are terms for the sects and subdivisions of the Jewish and Christian communities. 
"freedom of practice of religious rites." The Court interpreted the "freedom of belief" as a guarantee to practice one's belief unhindered, and made the following qualifications:

The first of these two [i.e. the freedom of belief] is unrestricted, while the second [i.e. the practice of this belief] may be restricted by means of its [internal] order to affirm some of its highest interests, and in particular on the grounds of preserving public policy and moral values [al-nizam al-'amm wa al'adab] and to the protection of the rights and freedoms of others. ${ }^{61}$

The Court was of the opinion that the obligation to wear the veil was not an undisputable rule of Islamic law. Hence, it qualified as a practice rather than as a belief, and therefore, was open to limitations in the interest of public policy; in this case the dress code at school was part of the supervising function of the governmental function of supervising education.

The same reasoning has been applied by the Court of Cassation and the Administrative Courts in matters of apostasy (that until now has not been a subject dealt with by the Constitutional Court): where the freedom of belief implies that one could never be forced to become a Muslim, once a person is a Muslim, he has to submit to the rules of Islam as a matter of the practice of that religion. In 1980, the Supreme Administrative Court phrased this as follows:

Since Islam protects the freedom of belief-for Islam may not be forced on anyone-freedom of belief as granted by the Constitution means that each individual may freely embrace whichever religion he believes without constraint. However, this freedom does not restrict the application of the Islamic Shari'a to those who embrace Islam. The State's religion is Islam. . . . Since the plaintiff has embraced Islam, he must then submit to its law which does not condone apostasy. ${ }^{62}$

The Court of Cassation has ruled in similar wordings in several cases, the last being the Abu Zayd case:

The purpose of entering Islam is to abide by its rules, including those of apostasy. . . . The rules for apostasy are no more than measures to keep a Muslim in his Islam, distinguishing him from others... This is what also happens in other religious laws with regard to their followers: they demand continuous loyalty to them. Once an individual joins in, he is to abide by its rules which can expel or segregate him if he violates their fundamental

61. Case No. 8, Year 17, 18 May 1996. See Bälz, The Secular Reconstruction of Islamic Law, supra note 40, at 229-44. Before the case came before the Supreme Constitutional Court, the Supreme Administrative Court had ruled that the decree did not conflict with the freedom of belief, but declared the decree void because it contravened the personal freedom to dress oneself according to one's wishes. (Case No. 4237, Year 40, 23 Aug. 1994.)

62. Case No. 20, Year 29, 8 Apr. 1980. 
principles which he embraced. . . . Certain religious laws . . . consider a difference of religion an impediment to marriage which prevents its conclusion, and they consequently impose separation or divorce. The same applies when one of the spouses embraces another religion. This does not violate the freedom of belief. ${ }^{63}$

\section{PUBLIC POLICY (3)}

According to the case law of the three highest Egyptian civil courts, neither the act of apostasy, nor its legal consequences, are related to the freedom of religion. Apostasy in the courts' definition does not pertain to a freedom of belief, which is interpreted as the right to practice one's belief free of any coercion or prejudice. Apostasy is part of the practice of a belief, the regulation of which is left to the "internal order" of that particular religion. It is the freedom of the internal order of that religion to prohibit or allow apostasy, as it is the freedom of that order to stipulate marriage impediments based on, for instance, the difference in religion between the spouses.

While the freedom of belief may not be restricted, conditions can be made on the freedom of its practice. These conditions are related to public policy, albeit in different ways. First, both the Egyptian Constitution (in the interpretation of the Supreme Constitutional Court $^{64}$ ) and the ICCPR ${ }^{65}$ allow for this freedom to be restricted on the basis of public policy. This can work two ways. For one, religious practice may be restricted for considerations of government policy, which also, confusingly, is referred to as "public policy." This may force the authorities to impose limitations-as in the "battle over the veil" case. On the other hand, when some of these religious practices themselves pertain to public policy, they are not to be restricted in any way whatsoever. As it turns out, Egyptian public policy does not allow apostasy, and therefore, this prohibition may not be tempered by a "free" practice of Islam.

In the Abu Zayd case, the restrictions on the freedom to practice Islam were carried even further when, in this instance, the Court of Cassation argued that a Muslim making public statements contrary to the orthodoxy of Islam violates Egyptian public policy. The Court did not interpret this in terms of freedom of religion, however, but as a matter of freedom of opinion (Article 47 Constitution):

63. Similar rulings were No. 20, Year 34, 30 Mar. 1966; No. 162, Year 62, 16 May 1995.

64. Case No. 20, Year 29, 8 Apr. 1980.

65. ICCPR, supra note 52, art. 18 (3) in fact stipulates: "Freedom to manifest one's religion or beliefs may be subject only to such limitations as are prescribed by law and are necessary to protect public safety, order, health or morals or the fundamental rights and freedoms of others." (emphasis added). 
To depart from Islam is to revolt against it, and this necessarily finds its reflection in the loyalty of the individual to the Shari'a, the state, and his ties with the society. This is what no law or state tolerates. Hence, the Shari'a and all other constitutions and laws permit freedom of opinion within the limits of public policy that prohibits wrong doing or misuse of a right. No individual has the right to call for what contradicts the public policy or moral values (al-nizam al'amm aw al-'adab), or use his opinion to harm the fundamentals upon which the society is built, or to revile the sacred things, or to disdain Islam or any other heavenly religion. ${ }^{66}$

The latter use of public policy shows the duality of apostasy in Egyptian legal discourse: a strict distinction is being made between the legal consequences of apostasy, which are merely perceived as a legal impediment in matters of personal status, and the acts leading to apostasy, such as pronouncing unbelief or blasphemy, resulting in the violation of public morals. Both are related to public policy, but differently: in the first case, public policy is the justification for the strict adherence to the rules of apostasy, while in the second case, public policy serves as the protecting shield for the orthodoxy of Islam.

\section{CONCLUSION}

The prohibition of apostasy for a Muslim, as defined in Islamic law, is enforced in all its consequences in Egypt, except for the death penalty. This prohibition has no foundation in legislation, but is based directly on Islamic law, which, in turn, is mentioned in several Egyptian laws as a source of law. The three highest civil courts in Egypt, the Court of Cassation, the Supreme Constitutional Court, and the Supreme Administrative Court of the State Council, have upheld this rule for at least the past half century. The prohibition of apostasy, the courts agree, is one of the rules that come with being a Muslim. And being a Muslim is as inalienable a part of a person as one's color or sex.

There is a blatant contradiction between, on the one hand, the prohibition of apostasy and, on the other hand, the constitutional guarantee of "freedom of belief" and similar provisions in the international human rights treaties to which Egypt has committed itself. The courts do not see this contradiction—or choose not to see it—-because they base their rulings on two assumptions. First, apostasy is one of the "definite" Islamic rules, and hence, is part of Egypt's public policy; that is, the fundamentals of the legal order. Second, the rules of apostasy are part of the freedom to practice one's

66. Egypt Const. art. 47. 
religion, which, according to both the Supreme Constitutional Court, as well as the ICCPR, is subject to restrictions of, inter alia, public policy. Hence, the prohibition of apostasy is considered to be outside the scope of unrestricted freedoms.

While the courts' position on the (Islamic) interpretation of apostasy itself has undergone no change in Egypt, the developments in the 1990s had serious repercussions. Until the 1990s, apostasy was mostly a clear situation of conversion, that is, an intentional act by a Muslim to convert to another religion. Usually, these converts had been Christians before becoming Muslim, and their conversions often were documented or otherwise easy to prove. Case law mainly dealt with the consequences of apostasy. During the 1990s, however, accusations of apostasy by third parties abounded, based on alleged blasphemous or heretical writings by the accused Muslim. These cases largely were instigated by the conservative religious establishment, in particular the Islamic Research Institute at Al-Azhar.

This caused the second feature of the 1990s to develop: a power struggle between Muslim jurists and the courts over the monopoly on authoritative interpretation of Islamic law, which appears to have been won by the courts. ${ }^{67}$ This was only possible because of the conservative position of these courts with regard to Islamic law. The Egyptian courts—especially the highest courts - are secular courts with a long-standing reputation of neutrality and non-partiality. However, when presented with questions on Islamic law, they show a tendency to embrace a conservative interpretation of Islam. This is not new-the courts have always done so. It was only when the Islamic religious discourse was taken to the court room that this attitude became more apparent. The courts have not become more Islamic, but they have been confronted with more "Islamic" cases than before. Nor is there a sudden increase of Islamic rules being incorporated into the order of the secular law, as some have argued. ${ }^{68}$ Islamic rules have always been part of the secular legal order. On many occasions in the past, the three courts have made clear that "definite" rules of Islamic law are fundamental to the Egyptian legal order. Few of these rules were codified, however, but retained their importance through public policy. As such, these Islamic rules become visible only in the case law of the Egyptian courts. Only now, with an increasing case load dealing with "Islamic" issues, does this essential character of the Egyptian legal order manifest itself more clearly.

Regardless of the unanimous opinion of the highest civil courts in Egypt on the prohibition of apostasy, for many it still represents a clear example of a human rights violation. Care should be taken, however, not to be drawn

67. See Bälz, The Secular Reconstruction of Islamic Law, supra note 40, at 243.

68. Id. at 237-38. 
too easily into the general discourse on human rights violations in Muslim countries. This discourse considers most human rights violations to be the result of the political atmosphere. This is correct for a majority of cases, and it is equally correct to conclude that many of these violations have nothing to do with Islam, even when Islam is used as a justification. ${ }^{69}$ But this political dimension is absent in the particular case of apostasy in Egypt: we are dealing with a sound rule of Islamic law that has been upheld for many decennia by a judiciary that generally is recognized as independent. By upholding this rule, the judiciary expresses a fundamental belief and, indeed, the public policy as perceived by a majority of Egyptian Muslims.

These established legal rules on apostasy, however, have become the subject of abuse. In the Abu Zayd case, the Egyptian judiciary has, for the first time, passed judgement on what an apostate is rather than on the legal consequences of apostasy. By defining apostasy in the Abu Zayd case, the Court of Cassation has ruled on the content of Islamic doctrine. All this was done in the name of public policy, i.e. the fundamental principles of the Egyptian society. The public policy that was initially aimed at protecting the adherence to specific rules regarding apostasy, however, has turned into the protection of Islamic doctrine at large.

69. See Heiner Bielefeld, Muslim Voices in the Human Rights Debate, 17 Hum. RTs Q. 595 (1995); F. Halliday, Relativism and Universalism in Human Rights: the Case of the Islamic Middle East, 43 Pol. Stud. 153 (1995); Mayer, supra note 50, at xvii. 